\title{
PREDICTORS OF EARLY-ONSET DEPRESSION AFTER FIRST-EVER STROKE
}

\author{
Tamara Rabi-Ž ikić ${ }^{1,2}$, Željko Živanović1,2, Vlado Đajić ${ }^{3,4}$ Svetlana Simić ${ }^{1,2}$, \\ Svetlana Ružička-Kaloci ${ }^{1,2}$, Sonja Slankamenac ${ }^{5}$ and Milorad Ž ikić $^{6}$ \\ ${ }^{1}$ Department of Neurology, Clinical Centre of Vojvodina, Novi Sad, Serbia; \\ ${ }^{2}$ University of Novi Sad, Faculty of Medicine, Department of Neurology, Novi Sad, Serbia; \\ ${ }^{3}$ Department of Neurology, Clinical Centre of Republic of Srpska, Banjaluka, \\ Republic of Srpska, Bosnia and Herzegovina; \\ ${ }^{4}$ University of Banjaluka, Faculty of Medicine, Banjaluka, Republic of Srpska, Bosnia and Herzegovina; \\ ${ }^{5}$ Department of Endocrinology, Diabetes and Metabolic Diseases, Clinical Centre of Vojvodina, Novi Sad, Serbia; \\ ${ }^{6}$ Global Prevent, Institute for Occupational Health, Novi Sad, Serbia
}

\begin{abstract}
SUMMARY - Post-stroke depression (PSD) is a severe and frequent stroke complication and one of the crucial factors for the outcome of rehabilitation and life quality after stroke. However, mood disorders frequently remain unnoticed and therefore untreated. The aim of the study was to examine all the potential risk factors and determine the independent predictors of early-onset depression after first-ever stroke, which would help identify high-risk patients, establish early diagnosis and timely treatment that would improve the course and prognosis of this disorder. This prospective study included 60 patients treated for their first-ever stroke; there were 30 patients diagnosed with depression and 30 patients without depression. The study included collection and analysis of all socio-demographic and clinical risk factors for PSD. Testing was performed two weeks after stroke. Depression was diagnosed according to the Mini International Neuropsychiatry Interview, DSM-IV diagnostic criteria, and depression severity was quantified by the Hamilton Depression Rating Scale. Cognitive impairment was assessed by the Mini Mental State Examination. Neurological deficit was assessed by the US National Institute of Health Stroke Scale. Our results showed that the independent predictors of early-onset depression after stroke were previous depressive episodes, cognitive dysfunction, and more severe neurological deficit.
\end{abstract}

Key words: Stroke; Depression; Quality of life; Mood disorders; Risk factors; Early diagnosis

\section{Introduction}

Post-stroke depression (PSD) is defined as a depressive disorder that occurs after acute focal cerebrovascular event, that is, in the context of clinically evident stroke. It is a severe and frequent stroke complication, considering the fact that depressive disorder develops at some time after stroke in even 33\% of pa-

Correspondence to: Tamara Rabi Žikic, MD, Department of Neurology, Clinical Centre of Vojvodina, University of Novi Sad, Faculty of Medicine, Novi Sad, Serbia

E-mail: tamara.rabi-zikic@mf.uns.ac.rs

Received September 20, 2019, accepted October 22, 2019 tients ${ }^{1}$. It is well known that patients with comorbidities have worse functional outcome after stroke ${ }^{2}$, and that major depression is one of the crucial factors for rehabilitation and life quality after stroke ${ }^{3}$. Yet, studies have shown that mood disorders most frequently go unrecognized and untreated ${ }^{4}$.

However, establishing a depression diagnosis is usually complicated in patients that survived stroke. This particularly refers to the acute stroke stage, when patients have a tendency not to regard their mood disorder symptoms as part of depression, but rather deny it or somatise and interpret them as the stroke sequel ${ }^{5}$. PSD in the acute stage may have a different mecha- 
nism of occurrence in relation to the subacute or chronic phase, thus their phenomenology, pathophysiology and risk factors should be examined separately ${ }^{6}$.

On examining negative repercussions of PSD on patient recovery, it is important to recognize those patients who are at the highest risk to develop depression. Research regarding risk factors for the occurrence of PSD that has been done so far shows that the biggest emphasis is put on the localization of the cerebral lesion as a specific clinical entity related to the focal damage of neurotransmitter pathways ${ }^{7,8}$. Much less effort has been invested in the study of the other potential risk factors such as socio-demographic factors, environmental risk factors and clinical factors, with the study results done so far being inconsistent ${ }^{9-12}$. In the light of this, the aim of our study was to examine all the potential risk factors and determine the independent predictors of early-onset depression after first-ever stroke, which would help identify high-risk patients, establish early diagnosis and timely treatment, thus improving the course and prognosis of this disease.

\section{Patients and Methods}

This prospective single-centre study included 60 patients over 18 years of age, of both sexes, who were treated at the Department of Neurology, Clinical Centre of Vojvodina, Novi Sad, Serbia, for their clinically first-ever stroke. Research was conducted over a 6-month period and completed in early 2018. One group consisted of 30 patients not diagnosed with depression in the acute phase of stroke. The other group consisted of 30 patients diagnosed with depression two weeks after the stroke.

The study was designed and conducted in accordance with the principles of the Declaration of Helsinki and approved by the hospital Ethics Committee. A written informed consent was obtained from the patients.

The inclusion criteria were first-ever symptomatic stroke (ischemic or hemorrhagic) verified by brain computed tomography (CT) and/or brain magnetic resonance imaging (MRI), and the Mini Mental State Examination (MMSE) score over 10. The exclusion criteria were the presence of previous physical disability due to other neurological, orthopedic or rheumatic diseases, impaired consciousness, sensorimotor aphasia, severe somatic disease that would prevent patient follow up, and suicidal ideas.

The study included collection and analysis of the following socio-demographic and clinical risk factors for PSD: gender, marital status, education, employment, financial status (satisfactory or unsatisfactory), place of living (urban or rural environment), a significant negative event in life within six months preceding the stroke, the presence of risk factors for cerebrovascular diseases (hypertension, diabetes mellitus, hyperlipoproteinemia, obesity, heart diseases, smoking, alcoholism), previously verified depression disorders, previously verified other psychiatric disorders, positive family history for depression disorders, positive family history for other psychiatric disorders, characteristics of brain lesion (type, location and size), the presence of silent strokes and presence of cortical and subcortical atrophy.

During hospitalization, in the acute phase of stroke, all patients underwent brain CT and/or brain MRI. Neurological, neuropsychiatric and neuropsychological tests were performed in all patients two weeks after stroke onset (to fulfill the ICD-10 diagnostic criteria for a depressive episode). Depression was diagnosed using the Mini International Neuropsychiatric Interview (MINI), (Serbian version/DSM IV 4.4), which is designed as a concise structured interview adapted to the diagnosis of depressive disorder in both the DSMIV and ICD-10 classifications. Depression severity was quantified using the Hamilton Depression Rating Scale (HDRS) that provides a quantitative measure of depression severity in a patient already diagnosed. The shorter version of 17 items (HDRS 17), which has always been much more used, quantifies the severity of depression so that scores $0-7$ mean no depression, scores 8-15 mean minor depression, and scores $\geq 16$ mean major depression. Cognitive impairment was assessed by the MMSE. It is the most widely used instrument for the evaluation of intellectual efficacy disorders and presence of intellectual deterioration. It consists of 11 questions examining different cognitive areas. The total score ranked from a minimum of 0 to maximum of 30 (no cognitive deficit), where cognitive impairment corresponds to score $\leq 25$. Neurological deficit was assessed by the US National Institute of Health Stroke Scale (NIHSS). 


\section{Statistical analysis}

Statistical analysis was performed using the SPSS (v. 13) statistical software. Data were analyzed using basic descriptive statistics, such as absolute and relative numbers, arithmetic mean and standard deviation. Statistical significance of differences in the obtained results was assessed using Student's t-test and $\chi^{2}$-test. Association of interval variables was analyzed using Pearson's correlation coefficient.

The multivariate binary logistic regression analysis was used for detection of statistically significant independent predictors of PSD. Information on the occurrence of depression was used as a dependent variable, and risk factors as independent predictors.

\section{Results}

There were more women in the group of depressed patients $(53 \%)$, whereas there were more men in the group of non-depressed patients (77\%). This difference in gender distribution between the groups was statistically significant $(\mathrm{p}=0.034)$. The mean age of women with stroke who developed depression was $63.1 \pm 6.6$, whereas the mean age of men with depression was $61.1 \pm 7.5$ years, and this difference was nonsignificant $(\mathrm{p}=0.445)$. Most of the non-depressed patients were married (80.0\%), and fewest were widowers/widows (6.7\%). There were $53.3 \%$ of married patients and $36.7 \%$ of widowers/widows with depression. The difference in marital status between the groups was statistically significant $(p=0.019)$. Differences but not statistically significant were recorded between the groups of depressed and non-depressed patients according to the level of education ( $p=0.156)$, employment $(\mathrm{p}=0.261)$, presence of financial problems $(p=0.531)$ and place of living in urban or rural environment $(\mathrm{p}=0.605)$.

A statistically significant difference was found between depressed and non-depressed patients according to the existence of a major negative life event within six months preceding stroke $(p=0.003)$. In the group of depressed patients, the most frequent life events were serious illness of a family member (13.3\%) and death of a close person (10\%), followed by divorce (6.7\%) and conflict with a family member (6.7\%). A single depressed patient mentioned court proceedings and tearing down a house with moving to a new house within the same area as a previous life event (Table 1 ).
Table 1. Baseline socio-demographic characteristics in depressive and non-depressive patients

\begin{tabular}{|l|l|l|l|}
\hline $\begin{array}{l}\text { Socio- } \\
\text { demographic } \\
\text { characteristic }\end{array}$ & Depressive & Non-depressive & $\mathrm{p}$ \\
\hline $\begin{array}{l}\text { Gender } \\
\text { (\% female) }\end{array}$ & $53.3(16)$ & $23.0(7)$ & 0.034 \\
\hline Age & $\begin{array}{l}62.1 \\
(\mathrm{sd}=3.57)\end{array}$ & $\begin{array}{l}61.7 \\
(\mathrm{sd}=4.54)\end{array}$ & 0.847 \\
\hline $\begin{array}{l}\text { Marital status } \\
(\% \text { married })\end{array}$ & $53.3(16)$ & $80.0(24)$ & 0.019 \\
\hline $\begin{array}{l}\text { Education } \\
(\% \text { elementary } \\
\text { school })\end{array}$ & $56.7(17)$ & $33.3(10)$ & 0.156 \\
\hline $\begin{array}{l}\text { Employment } \\
(\% \text { retired })\end{array}$ & $80.0(24)$ & $73.3(22)$ & 0.261 \\
\hline $\begin{array}{l}\text { Financial status } \\
(\% \text { satisfactory) }\end{array}$ & $73.3(22)$ & $83.3(25)$ & 0.531 \\
\hline $\begin{array}{l}\text { Urban } \\
\text { environment }\end{array}$ & $43.3(13)$ & $53.3(16)$ & 0.605 \\
\hline $\begin{array}{l}\text { Negative life } \\
\text { event }\end{array}$ & $43.3(13)$ & $6.7(2)$ & 0.003 \\
\hline
\end{tabular}

Prevalence of patients is shown in parentheses (except for age where it is standard deviation).

Positive family history of a previous depressive episode that was verified by a general practitioner or psychiatrist was recorded in $26.7 \%$ of patients, whereas another $33.3 \%$ of patients were aware of the previous depressive episode based on self-assessment, which indicated that $60 \%$ of the patients with depression had a previous depressive episode. In the group of non-depressed patients, none of the patients had depression earlier. This difference was statistically highly significant $(\mathrm{p}<0.001)$. In the group of depressed patients, previous depressive episodes were recorded in 56.3\% of women and $64.3 \%$ of men, yielding no statistically significant difference $(p=0.940)$. In our study, information on other verified psychiatric disorders was not obtained from any patient. There was a difference according to the existence of psychiatric disorders in the family; however, it did not reach statistical significance.

The percentage of all risk factors for stroke analyzed (hypertension, diabetes mellitus, hyperlipoproteinemia, obesity and heart diseases) was higher in depressed patients. However, a statistically significant difference between the examined groups was found only for obesity $(p=0.014)$. Smoking and excessive al- 
Table 2. Percent and prevalence of cerebrovascular risk factors in depressive and non-depressive patients

\begin{tabular}{|l|l|l|l|l|l|}
\hline & Cardiac disorder & Obesity & Hyperlipidemia & Diabetes mellitus & Hypertension \\
\hline Depressive & $53.3 \%(16)$ & $50.0 \%(15)$ & $73.3 \%(22)$ & $36.7 \%(11)$ & $93.3 \%(28)$ \\
Non-depressive & $26.7 \%(8)$ & $16.7 \%(5)$ & $70.0 \%(21)$ & $26.7 \%(8)$ & $90.0 \%(27)$ \\
$\mathrm{p}$ & 0.065 & 0.014 & 1.000 & 0.579 & 1.000 \\
\hline
\end{tabular}

Prevalence of patients with risk factors is shown in parentheses.
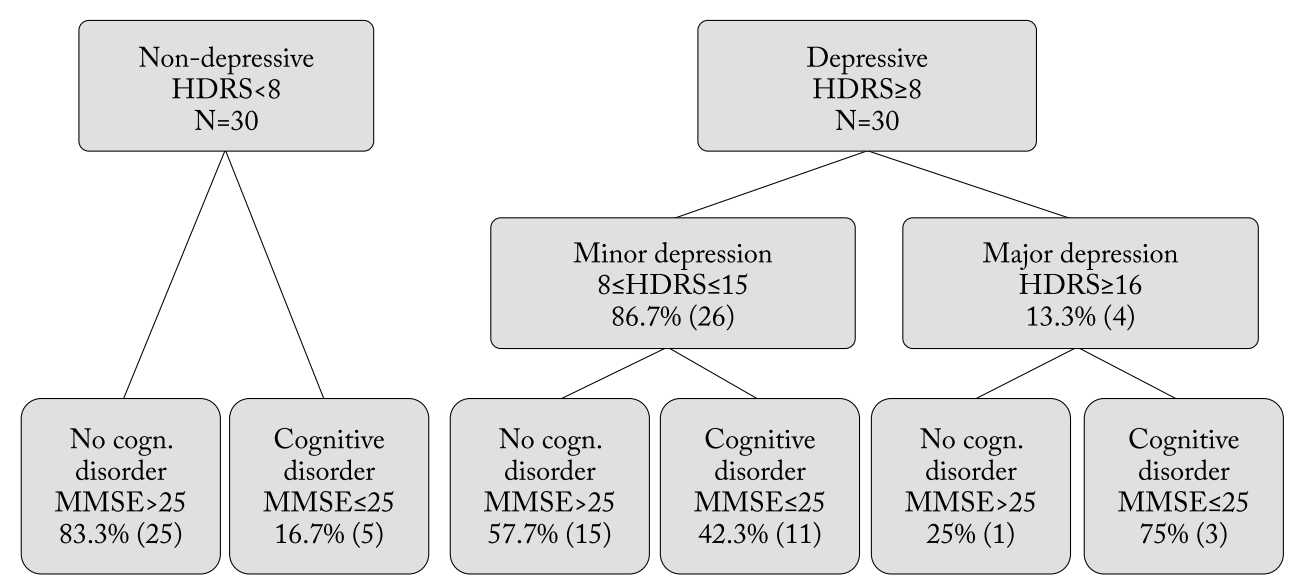

Fig. 1. Flow chart of patients with or without cognitive disorder in depressive and non-depressive groups.

HDRS = Hamilton Depression Rating Scale; MMSE = Mini-Mental State Examination score

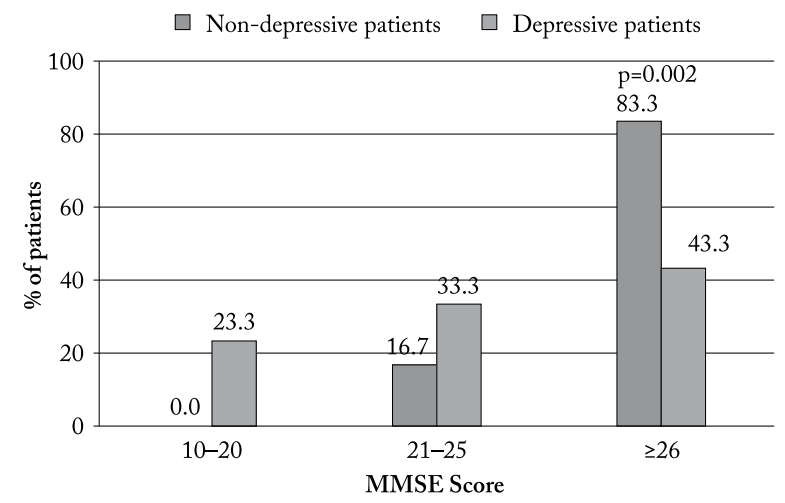

Fig. 2. Patient distribution according to the level of cognitive impairment.

MMSE $=$ Mini-Mental State Examination score

cohol consumption were more frequently recorded in depressed patients, but the difference was not statistically significant (Table 2).

There was no statistically significant difference in the lesion location between depressive and non-de-

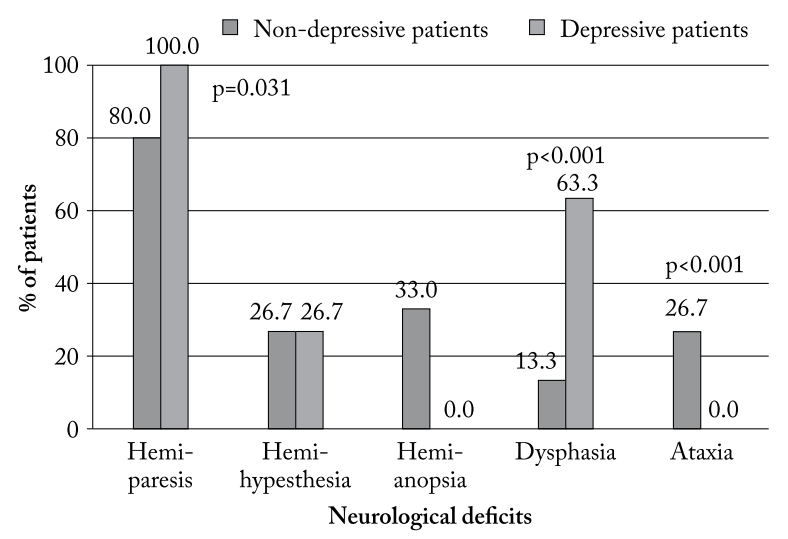

Fig. 3. Patient distribution according to neurological deficit.

pressive groups of patients, but it is evident that in depressed patients, lesion was most frequently localized in the left (dominant) cerebral hemisphere. Patients with left-sided frontal lesion or in left basal ganglia were not found to develop depression more frequently 
than patients with localization in other supratentorial regions $(\mathrm{p}=0.969)$. Infratentorial localization of lesion was recorded in $30 \%$ of patients without depression and $10 \%$ of patients with depression, which is evidently less, but there was no significant difference either $(\mathrm{p}=0.107)$. The groups of patients did not differ significantly according to the presence of silent strokes, cortical and subcortical atrophy.

Cognitive impairment (MMSE score $\leq 25$ ) was found in $16.7 \%$ of non-depressed patients (HDRS $<8$ ), $42.3 \%$ of patients with minor depression (HDRS $8-15)$ and $75 \%$ of patients with major depression (HDRS $\geq 16)(\mathrm{p}<0.001)$ (Fig. 1).

In the group of patients with depression, $43.3 \%$ did not have dementia, 33.3\% had moderate dementia (MMSE score 21-25), and 23.3\% had moderately severe dementia (MMSE score 10-20). In the group of non-depressed patients, $83.3 \%$ did not have dementia, $16.7 \%$ had moderate dementia, while moderately severe dementia was not recorded in any patient. The difference in distribution was statistically significant $(p=0.002)$. Correlation between the severity of depression (HDRS score) and severity of cognitive impairment (MMSE score) in the acute phase of stroke was $\mathrm{r}=-0.320(\mathrm{p}=0.084)$ and was not statistically significant (Fig. 2).

Considering the neurological status, significantly higher average values of NIHSS score (7.6) were recorded in the group of patients with depression than in patients without depression (5.2) $(\mathrm{p}<0.001)$. A statistically significantly larger number of patients with depression had hemiparesis or hemiplegia $(\mathrm{p}=0.031)$ and dysphasia $(p<0.001)$. Correlation of the values of HDRS and NIHSS score in the acute stage of stroke was $r=0.336(p=0.069)$ in the group of non-depressed patients and $r=0.462(p=0.010)$ in the group of depressed patients (Fig. 3).

\section{Multivariate analysis}

All the risk factors found to be significantly different in bivariate analyses of the groups of patients with and without PSD were included in binary logistic regression as predictors. Binary logistic regression was conducted in order to create a PSD prediction model based on socio-demographic and clinical patient variables obtained after their first evaluation (two weeks after stroke).
Table 3. Model coefficients of the model for prediction of PSD (PSD FC model)

\begin{tabular}{|l|l|l|}
\hline Model variable & $\mathrm{B}$ & $\mathrm{p}$ \\
\hline Previous depressive episode & -14.2 & 0.789 \\
MMSE $\leq 25$ & -3.21 & 0.012 \\
NIHSS $(>6)$ & -4.00 & 0.004 \\
Model constant & 16.6 & 0.754 \\
\hline
\end{tabular}

$\mathrm{PSD}=$ post-stroke depression; $\mathrm{FC}=$ forward conditional; $\mathrm{MMSE}$ = Mini-Mental State Examination score; NIHSS = NIH Stroke Scale score

Dependent variable in this logistic regression model was the occurrence of depression, while the predictors were gender (female), bachelorhood, previous negative events, obesity, cardiac disorders, previous depressive episodes, supratentorial lesion, lesions in the left hemisphere, lesions in the front circulation, MMSE $\leq 25$ and NIHSS $>6$ (Table 3 ).

The model used in this research was forward conditional, in which variables are introduced one by one into the model exclusively based on the individual statistical significance regarding improvement of the model quality. Using this method, three statistically significant independent predictors of PSD occurrence were retained in the model, as follows: previous depressive episodes, MMSE $\leq 25$ and NIHSS $>6$.

Based on this model, the prediction accuracy was 96.7\% (29/30) in patients without PSD and 90.0\% (27/30) in depressed patients. The overall prediction accuracy of the created model was $98.3 \%$ (59/60). The Hosmer and Lemeshow Goodness-of-Fit Test was not significant $(p=0.998)$, which indicated adequate model fit.

\section{Discussion}

The real cause of these gender-based differences has not yet been determined in primary depression; however, the assumptions are mainly based on different hormonal influences and the social role of women in the modern society ${ }^{13}$. Most studies have shown that women develop significantly more depression after stroke than men, which was also confirmed in our study ${ }^{14-16}$. However, the results of the research that did not find an important gender difference between patients cannot be neglected ${ }^{9,17,18}$, and so cannot be the studies demonstrating that male patients of a younger 
age developed significantly more PSD than women ${ }^{19,20}$. There also are opinions that PSD can be of a different nature in men and women, whereby physical disability can be of greater importance to men during the period when they are workable ${ }^{19}$. Many studies conducted so far have caused a lot of controversy regarding patient age. As the most valuable findings, we should consider a systematic review of the literature, where the connection between age and depression was not found ${ }^{9}$, reporting results consistent with our results. In our analysis of the patient marital status, we found a statistically significant difference $(\mathrm{p}=0.013)$ between the groups of depressed patients and non-depressed patients. These results are consistent with the findings of other studies, which show that patients who lead the life of a single person are more prone to develop $\mathrm{PSD}^{21}$, considering that social isolation or lack of social support are significant factors in PSD development. In a relatively small number of studies, level of education, employment and socioeconomic status are considered as the potential PSD risk factors. In some of these studies, the connection between the level of education and the severity of depression symptoms was not found ${ }^{9,22}$, which is consistent with our findings. However, in one of the larger population studies conducted in the USA, the results indicated the level of education to be protective concerning PSD development ${ }^{23}$. Furthermore, in our research, there was no statistically significant difference considering the percentage of employed people included in the study. Yet, in a long-term population study conducted during an average period of six years in a group of younger patients who were unemployed or lost their jobs, a significant correlation with PSD was found ${ }^{24}$. These discrepancies among the studies considering socio-demographic status are somewhat expected, taking into account individual differences, different environments, cultures, religions, customs and education. All these factors, alongside the factors determined by stroke itself, create more or less suitable conditions for PSD development.

Negative life events experienced six months prior to stroke were found to be a high risk factor for PSD development in many studies ${ }^{25}$. The results of our research are consistent with literature data. A negative life event experienced six months prior to stroke was recorded in a significantly higher percentage in the group of patients with PSD than in non-depressed pa- tients $(\mathrm{p}=0.003)$. In our study population, the most common life events asserted where those connected to family, i.e. death, serious disease, conflict with a family member, or divorce.

Risk factors for cerebrovascular diseases such as hypertension, diabetes and heart diseases, all together represent diseases connected to primary depression. Furthermore, depressed people are more prone to smoking and alcohol abuse; in addition, overweight women are also known to suffer from primary depression more frequently ${ }^{13}$. The distribution of risk factors for cerebrovascular diseases varies depending on age, gender and stroke subtype ${ }^{26}$, but research done so far has rarely considered the influence of these factors on PSD development. The exception to this is a great prospective population study $(\mathrm{N}=134)$, with a conclusion that patients having survived stroke have a significantly higher risk to develop depression, independently of risk factors for cerebrovascular diseases ${ }^{23}$. However, there are studies that show that risk factors for cerebrovascular diseases immediately increase the risk of depression ${ }^{27}$. In our research, hypertension, diabetes and heart disease especially, were present at a higher percentage in depressed patients, but the difference was not statistically significant. In predicting PSD, it may be more important to observe the length of these factors, their severity, as well as the treatment administered than the mere presence of factors, since they are certain in patients who have a stroke. The only statistically significant difference found between our groups $(p=0.014)$ referred to obesity, hence our results confirm once more that obesity is closely related to a depression disorder. Although the connection between alcohol abuse and depression disorders is well known, alcoholism as a PSD risk factor was not studied enough. Only one prospective population study conducted amongst young adults found that alcoholism before a stroke significantly increased the risk of developing $\mathrm{PSD}^{24}$. Our research also showed that smoking and alcohol abuse were much more common in depressed than in non-depressed patients, however, the difference was statistically nonsignificant.

Most studies have shown that prior affective disorders are an independent predictor of $\mathrm{PSD}^{21,28}$. In our study, none of the non-depressed patients and $60 \%$ of depressed patients had prior depression disorders, yielding a statistically significant difference $(\mathrm{p}=0.019)$. In these patients, PSD could be just an exacerbation of 
earlier mood disorders, i.e. the situations in which somatic diseases just reveal the existing mood disorder. Logistic regression analysis in our research indicated that previous depression episodes were independent predictors of depression developed early after stroke. In our research, none of our patients had verified some other psychiatric disorder in periods prior to stroke. In other studies, positive family history of other psychiatric disorders was significantly connected to major depression after stroke ${ }^{29}$. The hypothetical mechanism is genetic vulnerability. In our study, the difference in the familial history of psychiatric disorders between the study groups was statistically nonsignificant ( $p=0.094)$.

The connection between lesion location and PSD was a subject of many studies ${ }^{7,30}$. Many important studies found PSD to be more common in patients with left-sided frontal lesions or in basal ganglia in the first months after stroke ${ }^{8,31,32}$. However, many studies did not find any connection between depression and lesion location ${ }^{33}$. There also are opinions that these findings reflect different behavioral presentations of stroke, since patients with left-sided lesions have catastrophic reactions, whereas patients with right hemisphere lesions are characterized with loss of situation insight and neglect. These behavioral differences decreased with time ${ }^{33}$. In our research, we did not find any evidence for PSD and lesion location connection. Depression is not more common in patients with left frontal or left basal ganglia lesions than in those whose lesions are localized in other sites. Our results are consistent with the findings reported by Carson et al. ${ }^{34}$ in their meta-analysis, which is in all likelihood the most comprehensive meta-analysis in the literature. This heterogeneity of findings concerning connection between PSD and lesion location is in favor of those who report that PSD (at least partially) is a manifestation of cognitive and functional damage rather than the result of damage to certain brain regions $s^{35}$. In our study, a higher frequency of lacunar stroke was detected in non-depressed patients and of partial strokes in depressed patients. However, the differences were statistically nonsignificant $(\mathrm{p}=0.375)$. Schmidt et al. showed that patients with silent strokes suffered more cognitive impairment and depression symptoms than those without them ${ }^{36}$. These findings could suggest that PSD might not be a consequence of only acute, clinically evident strokes, but also that silent strokes could be directly related to depression. However, many other studies have not considered silent strokes as a potential PSD risk factor ${ }^{35}$. In most of our patients, silent strokes were recorded, however, the difference between the groups was statistically nonsignificant $(p=0.159)$. In search for PSD predictors, Starkstein et al. found significantly larger subcortical atrophy in patients with major depression, with assumption that this atrophy makes patients more prone to develop PSD ${ }^{37}$. However, there are studies, which found no connection between depression symptoms and cerebral atrophy, which is consistent with our results.

The natural connection between depression and cognitive dysfunctions represents complex interaction among depression, cerebral lesions and cognitive impairment, but depends also on numerous factors such as age, gender, education level, length of time elapsed after stroke, depression severity, and the side of cerebral lesions ${ }^{38}$. While some researches find that cognitive impairment leads to depression symptoms ${ }^{39}$, others indicate that PSD leads to cognitive dysfunctions, partially reversible, if depression disorders are in remission ${ }^{40}$. However, some researches show that these two are independent disorders ${ }^{29}$. Furthermore, there is a popular assumption that cognitive dysfunction and depression develop as a result of a third factor such as serotonergic dysfunction caused by left hemisphere le$\operatorname{sion}^{41}$. In our research, we found that cognitive impairment was significantly more severe in depressed than in non-depressed patients $(p<0.001)$. Difference between the study groups was also statistically significant regarding cognitive impairment level. Multivariate logistic regression analysis in our study indicated cognitive dysfunctions to be independent predictors of early-onset depression after stroke. Nowadays, the real PSD prevalence is unknown in patients with aphasia since most researchers exclude patients because of moderate to severe damage. Broca's aphasia is more commonly connected with depression since these patients are more aware of their damage ${ }^{42}$. The behavior of patients with Wernicke aphasia is described as euphoric, rarely scared and paranoid, but never depressive. In the present study, we found significantly more depressed patients with dysphasia compared with non-depressed patients $(\mathrm{p}<0.001)$.

The severity of the initial neurological deficit can be considered as the most important predictor of functional disability. A more severe neurological deficit is most commonly the consequence of a larger cerebral 
lesion that affected the areas that are involved in cognitive functions and mood regulation. Most studies performed so far indicate that depressed patients have significantly more severe initial neurological deficit than non-depressed patients ${ }^{18,24}$, and that the severity of neurological deficit is an independent predictor of $\mathrm{PSD}^{12,43,44}$. This was also confirmed by our results recorded in patients having developed early-onset PSD. The average NIHSS score was significantly higher $(\mathrm{p}<0.001)$ in depressed than in non-depressed patients, as well as in patients with hemiparesis or hemiplegia $(\mathrm{p}=0.031)$ and dysphasia $(\mathrm{p}<0.001)$. In addition, none of the depressed patients was without extremity weakness. Ataxia was not found in depressed patients, while in the non-depressed group ataxia was present in about one-quarter of patients. This less frequent connection between ataxia and depression is probably linked to the fact that ataxia is a consequence of cerebellum or brain stem lesions, which are parts of the brain not involved in regulating affective or cognitive functioning. The other possible explanation would be that ataxia is less unsuitable for patients in psychological sense than extremity weakness or dysphasia. Our findings could not be confirmed since there are no comparative data or similar analysis in the available literature.

Considering study limitations, this was a single center study that enrolled a relatively small number of patients, so future investigations and more extensive studies are required.

\section{Conclusion}

Post-stroke depression is more frequent in female patients, obese patients, patients who are single, patients who had a negative life event six months prior to stroke or had prior depression episodes. Our results showed that the independent predictors of early-onset depression after stroke were previous depression episodes, cognitive dysfunctions, and severe neurological deficit.

\section{References}

1. Hackett ML, Yapa C, Parag V, Anderson CS. Frequency of depression after stroke: a systematic review of observational studies. Stroke. 2005;36(6):1330-40. doi: 10.1161/01.STR.00 00165928.19135.35.

2. Simić-Panić D, Bošković K, Milićević M, Rabi Žikić T, Cvjetković Bošnjak M, Tomašević-Todorović S, Jovićević M.
The impact of comorbidity on rehabilitation outcome after ischemic stroke. Acta Clin Croat. 2018 Mar;57(1):5-15. doi: 10.20471/acc.2018.57.01.01.

3. Žikić TR, Divjak I, Jovićević M, Semnic M, Slankamenac P, Žarkov M, Žikić M. The effect of post stroke depression on functional outcome and quality of life. Acta Clin Croat. 2014 Sep;53(3):294-301. PMID:25509239.

4. Schubert DSP, Taylor C, Lee S. Detection of depression in the stroke patient. Psychosomatics. 1992;33:1-5. doi: 10.1016/ S0033-3182(92)71967-7.

5. Lincoln NB, Nicholl CR, Flannaghan T, Leonard M, Van der Gucht E. The validity of questionnaire measures for assessing depression after stroke. Clin Rehabil. 2003;17:840-6. First Published December 1, 2003 Research Article doi.org/ 10.1191 / 0269215503 cr687oa.

6. Whyte EM, Mulsant BH. Post stroke depression: epidemiology, pathophysiology, and biological treatment. Biol Psychiatry. 2002;52:253-64. doi: 10.1016/s0006-3223 (02) 01424-5.

7. Robinson RG, Kubos KL, Starr LB, et al. Mood disorders in stroke patients: importance of location of lesion. Brain. 1984; 107:81-93. doi: 10.1093/brain/107.1.81.

8. Rajashekaran P, Pai K, Thunga R, Unnikrishnan B. Post-stroke depression and lesion location: a hospital based cross-sectional study. Indian J Psychiatry. 2013 Oct;55(4):343-8. doi: 10.4103 /0019-5545.120546.

9. Hackett ML, Anderson CS. Predictors of depression after stroke: a systematic review of observational studies. Stroke. 2005;36(10):2296-301. doi: 10.1161/01.STR.0000183622.7 5135 .

10. Santos EB, Rodrigues RA, Pontes-Neto OM. Prevalence and predictors of post stroke depression among elderly stroke survivors. Arq Neuropsiquiatr. 2016 Aug;74(8):621-5. doi: 10.1590 /0004-282X20160088.

11. Vojtikiv-Samoilovska D, Arsovska A. Prevalence and predictors of depression after stroke - results from a prospective study. Open Access Maced J Med Sci. 2018 Apr 24;6(5):824-8. doi: 10.3889/oamjms.2018.182.

12. Wang L, Tao Y, Chen Y, Wang H, Zhou H, Fu X. Association of post stroke depression with social factors, insomnia, and neurological status in Chinese elderly population. Neurol Sci. 2016 Aug;37(8):1305-10. doi: 10.1007/s10072-016-2590-1.

13. Lisulov R, Nedić A. Problemi dijagnostike i lečenja depresivnih poremećaja u ustanovama primarne zdravstvene zaštite u AP Vojvodini. Novi Sad: Medicinski fakultet, 2006. (in Serbian)

14. Paolucci S, Gandolfo C, Provinciali L, Torta R, Sommacal S, Toso V. Quantification of the risk of poststroke depression: the Italian multicenter observational study DESTRO. Acta Psychiatr Scand. 2005;112:272-8. doi: 10.1111/j.1600-0447. 2005.00590.

15. Paradiso S, Robinson R. Gender differences in poststroke depression. J Neuropsychiatry Clin Neurosci. 1998;10:41-7. doi: 10.1176/jnp.10.1.41.

16. Cassidy E, O'Connor R, O'Keane V. Prevalence of post-stroke depression in an Irish sample and its relationship with disabil- 
ity and outcome following inpatient rehabilitation. Disabil Rehabil. 2004;26:71-7. doi:10.1080/09638280410001650142.

17. Åström M, Adolfsson R, Asplund K. Major depression in stroke patients: a 3-year longitudinal study. Stroke. 1993;24 (7):976-82. doi: 10.1161/01.str.24.7.976.

18. Volz M, Ladwig S, Werheid K. Gender differences in poststroke depression: a longitudinal analysis of prevalence, persistence and predictive value of known risk factors. Neuropsychol Rehabil. 2019 Aug 5:1-17. doi: 10.1080/09602011.2019. 1648301.

19. Berg A, Palomaki H, Lehtihalmes M, Lonnqvist J, Kaste M. Poststroke depression: an 18-month follow-up. Stroke. 2003; 34:138-43. doi: 10.1161/01. str.0000048149.84268.07.

20. Burvill PW, Johnson GA, Jamrozik KD, Anderson CS, Stewart-Wynne EG, Chakera TMH. Prevalence of depression after stroke: the Perth Community Stroke study. Br J Psychiatry. 1995;166:320-7. doi: 10.1192/bjp.166.3.320.

21. Naess H, Lunde L, Brogger J, Waje-Andreassen U. Depression predicts unfavourable functional outcome and higher mortality in stroke patients: the Bergen Stroke Study. Acta Neurol Scand Suppl.2010;(190):34-8. doi:10.1111/j.1600-0404.2010.01373.

22. Vojtikiv-Samoilovska D, Arsovska A. Socio-demographic characteristics of the patients with a post stroke depression from the Municipality of Tetovo, Republic of Macedonia. Open Access Maced J Med Sci. 2018 May 14;6(5):782-5. doi: 10.3889/oamjms.2018.201.

23. Whyte EM, Mulsant BH, Vanderbilts J, Dodge HH, Ganguli M. Depression after stroke: a prospective epidemiological study. J Am Geriatr Soc. 2004;52:774-8. doi: 10.1111/ j.1532-5415.2004.52217.

24. Naess H, Nyland HI, Thomassen L, Aarseth J, Myhr KM. Mild depression in young adults with cerebral infarction at a longterm follow-up: a population-based study. Eur J Neurol. 2005; 12:194-8. doi: org/10.1111/j.1468-1331.2004.00937.

25. Bush BA. Major life events as risk factors for post-stroke depression. Brain Inj. 1999;13:131-7. doi: org/10.1080/026990 599121791.

26. Rostohar Bijelić B, Petek M, Kadojić M, Bijelić N, Kadojić D. Distribution of stroke risk factors in eastern Croatia. Acta Clin Croat. 2018 Mar;57(1):103-9. doi: 10.20471 /acc. 2018.57. 01.12 .

27. Altieri M, Maestrini I, Mercurio A, Troisi P, Sgarlata E, Rea V, Di Piero V, Lenzi GL. Depression after minor stroke: prevalence and predictors. Eur J Neurol. 2012 Mar;19(3):517-21. doi: 10.1111/j.1468-1331.2011.03583.

28. Ng KC, Chan KL, Straughan PT. A study of post-stroke depression in a rehabilitative center. Acta Psychiatr Scand. 1995;92:75-9. doi: 10.1111/j.1600-0447.1995.tb09546.

29. Morris PLP, Robinson RG, Raphael B. Prevalence and course of depressive disorders in hospitalized stroke patients. Int J Psychiatr Med. 1990;20:349-64. doi: 10.2190/N8VU-6LWUFLJN-XQKV.
30. Vataja R, Pohjasvaara T, Leppavuori A, et al. Magnetic resonance imaging correlates of depression after ischemic stroke. Arch Gen Psychiatr. 2001;58(10):925-31. doi: 10.1001 /archpsyc. 58.10.925.

31. Bhogal SK, Teasell R, Foley N, Speechley M. Lesion location and poststroke depression: systematic review of the methodological limitations in the literature. Stroke. 2004;35:794-802. doi: 10.1161/01.STR.0000117237.98749.26.

32. Robinson RG, Jorge RE. Post-stroke depression: a review. Am J Psychiatry. 2016;173:221-31. doi: 10.1176/appi.ajp.2015. 15030363.

33. Narushima K, Kosier JT, Robinson RG. A reappraisal of poststroke depression, intra- and inter-hemispheric lesion location using meta-analysis. J Neuropsychiatr Clin Neurosci. 2003; 15(4):422-30. doi: 10.1176/jnp.15.4.422.

34. Carson AJ, MacHale S, Allen K, Lawrie SM, Dennis M, House A, Sharpe M. Depression after stroke and lesion location: a systematic review. Lancet. 2000;356:122-6. doi: 10.1016/ S0140-6736(00)02448-X.

35. Nys GMS, van Zandvoort MJE, van der Worp HB, de Haan EHF, de Kort PLM, Kappelle LJ. Early depressive symptoms after stroke: neuropsychological correlates and lesion characteristics. J Neurol Sci. 2004;228:27-33. doi: 10.1016/j.jns. 2004.09.031.

36. Schmidt WP, Roesler A, Kretzschmar K, Ladwig KH, Junker $\mathrm{R}$, Berger K. Functional and cognitive consequences of silent stroke discovered using brain magnetic resonance imaging in an elderly population. J Am Geriatr Soc. 2004;52:1045-50. PMID:15209640; doi: 10.1111/j.1532-5415.2004.52300.

37. Starkstein SE, Robinson RG, Price TR. Comparison of patients with and without poststroke major depression matched for size and location of lesion. Arc Gen Psychiatr. 1988;45:24752. PMID: 3341879; doi: 10.1001/ archpsyc. 1988. 018002 70061007.

38. Spalletta G, Guida D, De Angelis D, et al. Predictors of cognitive level and depression severity are different in patients with left and right hemispheric stroke within the first year of illness. J Neurol. 2002;249(11 Suppl):1541-51. PMID: 12420095; doi: 10.1007/s00415-002-0885-z.

39. De Ryck A, Brouns R, Fransen E, Geurden M, Van Gestel G, Wilssens I, De Ceulaer L, Mariën P, De Deyn PP, Engelborghs S. A prospective study on the prevalence and risk factors of poststroke depression. Cerebrovasc Dis Extra. 2013 Jan 26;3(1):1-13. doi: 10.1159/000345557.

40. Kimura M, Robinson RG, Kosier T. Treatment of cognitive impairment after poststroke depression. Stroke. 2000;31(7): 1482-6. PMID: 10884441; doi: 10.1161/01.

41. Davidson RJ. Cognitive neuroscience needs affective neuroscience (and vice versa). Brain Cogn. 2000;42:89-92. PMID: 10739607; doi: 10.1006/brcg.1999.1170.

42. Robinson RG, Benson DF. Depression in aphasic patients: frequency, severity and clinical-pathological correlates. Brain Lang. 1981;14:282-91. doi: org/10.1016/0093-934X(81) 90080-8. 
43. Karakus K, Kunt R, Memis CO, Kunt DA, Dogan B, Ozdemiroglu F, Sevincok L. The factors related to early-onset depression after first stroke. Psychogeriatrics. 2017 Nov;17(6): 414-22. doi: 10.1111/psyg.12266.
44. Meng G, Ma X, Li L, Tan Y, Liu X, Liu X, Zhao Y. Predictors of early-onset post-ischemic stroke depression: a cross-sectional study. BMC Neurol. 2017 Nov 17;17(1):199. doi: 10.1186/ s12883-017-0980-5.

Sažetak

\section{PREDIKTORI RANOG NASTUPA DEPRESIJE NAKON MOŽDANOG UDARA}

\section{T. Rabi-Žikić, Ž. Živanović, V. Đajī́ S. Simić, S. Ružička-Kaloci, S. Slankamenac i M. Žikić}

Depresija nakon moždanog udara je teška i česta komplikacija moždanog udara i jedan od ključnih čimbenika za ishod rehabilitacije i kvalitetu života nakon moždanog udara. Međutim, poremećaji raspoloženja ostaju najčešće neprepoznati, a samim tim i neliječeni. Cilj ovoga istraživanja bio je ispitati sve potencijalne čimbenike rizika i utvrditi nezavisne prediktore depresije koja se javlja rano nakon moždanog udara, a koji bi omogućili identifikaciju visokorizičnih bolesnika, postavljanje rane dijagnoze i pravodobno liječenje, što bi unaprijedilo tijek i prognozu ove bolesti. Prospektivno istraživanje obuhvatilo je 60 bolesnika liječenih zbog klinički prvog moždanog udara, od toga 30 bolesnika s dijagnosticiranom depresijom i 30 bolesnika bez depresije. Istraživanje je obuhvatilo podatke o svim socio-demografskim i kliničkim čimbenicima rizika za nastanak depresije nakon moždanog udara. Testiranja su provedena dva tjedna nakon moždanog udara. Depresija je dijagnosticirana prema Mini International Neuropsychiatry Interview, DSM-IV dijagnostičkim kriterijima, težina depresije kvantificirana je Hamiltonovom ljestvicom za procjenu depresivnosti (HDRS). Kognitivni status procjenjivao se pomoću Mini Mental State Examination (MMSE). Neurološki status se procjenjivao pomoću Ljestvice za moždani udar Nacionalnog instituta za zdravlje, SAD (NIHSS). Rezultati našega istraživanja ukazuju na to da su nezavisni prediktori ranog nastupa depresije nakon moždanog udara ranije depresivne epizode, kognitivne disfunkcije i teži neurološki deficit.

Ključne riječi: Moždani udar; Depresija; Kvaliteta života; Raspoloženje, poremećaji; Rizični čimbenici; Rana dijagnostika 